University of Nebraska - Lincoln

DigitalCommons@University of Nebraska - Lincoln

2016

\title{
Potential Direct and Indirect Effects of Climate Change on a Shallow Natural Lake Fish Assemblage
}

\author{
Jason J. Breeggemann \\ South Dakota State University \\ Mark A. Kaemingk \\ University of Nebraska - Lincoln, mkaemingk2@unl.edu \\ Timothy J. DeBates \\ Minnesota Department of Natural Resources \\ Craig P. Paukert \\ USGS Missouri Cooperative Fish and Wildlife Research Unit \\ Jacob R. Krause \\ South Dakota State University
}

See next page for additional authors

Follow this and additional works at: https://digitalcommons.unl.edu/natrespapers

Part of the Natural Resources and Conservation Commons, Natural Resources Management and Policy Commons, and the Other Environmental Sciences Commons

Breeggemann, Jason J.; Kaemingk, Mark A.; DeBates, Timothy J.; Paukert, Craig P.; Krause, Jacob R.; Letvin, Alexander P.; Stevens, Tanner M.; Willis, David W.; and Chipps, Steven R., "Potential Direct and Indirect Effects of Climate Change on a Shallow Natural Lake Fish Assemblage" (2016). Papers in Natural Resources. 685.

https://digitalcommons.unl.edu/natrespapers/685

This Article is brought to you for free and open access by the Natural Resources, School of at DigitalCommons@University of Nebraska - Lincoln. It has been accepted for inclusion in Papers in Natural Resources by an authorized administrator of DigitalCommons@University of Nebraska - Lincoln. 


\section{Authors}

Jason J. Breeggemann, Mark A. Kaemingk, Timothy J. DeBates, Craig P. Paukert, Jacob R. Krause, Alexander P. Letvin, Tanner M. Stevens, David W. Willis, and Steven R. Chipps 


\title{
Potential direct and indirect effects of climate change on a shallow natural lake fish assemblage
}

\author{
Jason J. Breeggemann', Mark A. Kaemingk' ${ }^{1}$, Timothy J. DeBates², Craig P. Paukert ${ }^{3}$, Jacob R. Krause ${ }^{1}$, \\ Alexander P. Letvin ${ }^{1}$, Tanner M. Stevens ${ }^{1}$, David W. Willis ${ }^{1}$, Steven R. Chipps ${ }^{4}$ \\ ${ }^{1}$ Department of Natural Resource Management, South Dakota State University, Brookings, SD, USA \\ ${ }^{2}$ Minnesota Department of Natural Resources, East Metro Fisheries, St. Paul, MN, USA \\ ${ }^{3}$ U.S. Geological Survey Missouri Cooperative Fish and Wildlife Research Unit, Department of Fisheries and Wildlife Sciences, University of Missouri, Columbia, \\ MO, USA \\ ${ }^{4}$ U.S. Geological Survey South Dakota Cooperative Fish and Wildlife Research Unit, Department of Natural Resource Management, South Dakota State \\ University, Brookings, SD, USA
}

Accepted for publication July 25, 2015

\begin{abstract}
Much uncertainty exists around how fish communities in shallow lakes will respond to climate change. In this study, we modelled the effects of increased water temperatures on consumption and growth rates of two piscivores (northern pike [Esox lucius] and largemouth bass [Micropterus salmoides]) and examined relative effects of consumption by these predators on two prey species (bluegill [Lepomis macrochirus] and yellow perch [Perca flavescens]). Bioenergetics models were used to simulate the effects of climate change on growth and food consumption using predicted 2040 and 2060 temperatures in a shallow Nebraska Sandhill lake, USA. The patterns and magnitude of daily and cumulative consumption during the growing season (April-October) were generally similar between the two predators. However, growth of northern pike was always reduced ( -3 to $-45 \%$ change) compared to largemouth bass that experienced subtle changes (4 to $-6 \%$ change) in weight by the end of the growing season. Assuming similar population size structure and numbers of predators in 2040-2060, future consumption of bluegill and yellow perch by northern pike and largemouth bass will likely increase (range: 3-24\%), necessitating greater prey biomass to meet future energy demands. The timing of increased predator consumption will likely shift towards spring and fall (compared to summer), when prey species may not be available in the quantities required. Our findings suggest that increased water temperatures may affect species at the edge of their native range (i.e. northern pike) and a potential mismatch between predator and prey could exist.
\end{abstract}

Key words: shallow lakes; temperature; climate change; predation; growth; predator-prey dynamics; bioenergetics; consumption

\section{Introduction}

The onset of climate change will likely affect most ecological processes and functions as well as influence living organisms both directly and indirectly by affecting their physiology, growth and behaviour (Petersen \& Kitchell 2001; Winder \& Schindler 2004 Pörtner \& Peck 2010); however, many uncertainties remain about the direction and/or magnitude of these alterations. For ectotherms such as fish, temperature shifts may have substantial impacts on the timing of reproduction, development, growth, mortality, recruitment and metabolism (Magnuson et al. 1979; Shuter \& Post 1990;
Tonn 1990; Brandt et al. 2002; Casselman 2002). Increased temperatures can affect fish metabolism by elevating metabolic demand to maintain cardiac function and respiration (Brown et al. 2004). Increased metabolism can lead to increased consumption rates that directly affect individual growth and survival rates (Christie \& Regier 1988) and can indirectly affect the fish assemblage structure through mechanisms such as competition and predation (Biro et al. 2007; McCarthy et al. 2009; Wuellner et al. 2010).

Despite the growing wealth of information on climate change and subsequent effects on fish populations in lotic cold-water systems, information is

Correspondence: Jason J. Breeggemann, Department of Natural Resource Management, South Dakota State University, Brookings, SD 57007, USA. E-mail: jason.breeggemann@sdstate.edu 


\section{Breeggemann et al.}

lacking on how fish communities will respond to climate change in warm-water ecosystems. Many changes will likely occur within these systems as well, with temperature having arguably one of the largest impacts (Walther et al. 2002). More attention has been given to individual species and how they might respond to changes in climate, while fewer studies have examined species interactions such as predatorprey dynamics. At higher temperatures, increased metabolic demands of predators must be met by similar increases in prey production to maintain balanced predatory-prey populations (Hill \& Magnuson 1990; Johnson et al. 2008; Wuellner et al. 2010). Gaining insight into the effects of climate change on fish communities is important for future conservation efforts and management decisions (Tonn 1990).

Modelling provides a valuable tool to explore the potential impacts of increased temperature on fish physiology and understanding how those changes affect piscivores and their prey base. Changes in seasonal water temperature could affect species interactions, food consumption and fish production. The changes in fish physiology and assemblage structure will likely be most substantial where fish species are at the edge of their native range and thus examining how predators respond to changes in temperatures may provide the most insight into assemblage level effects (Magnuson 2001; Casselman 2002). Specifically, bioenergetics modelling (Hanson 1997) provides a robust method to explore the temperature effects on individual physiology that has been applied to a wide variety of systems and species (e.g. Chipps \& Wahl 2008; Johnson et al. 2008; McCarthy et al. 2009). By accounting for temperature-dependence of fundamental energy budget components, bioenergetics modelling also offers insight to other processes that could be indirectly influenced by climate change (e.g. spawning phenology, recruitment, mortality and behaviour).

The objectives of this study were to model: (i) the direct effects of increased temperatures on consumption and growth rates of northern pike (Esox lucius) and largemouth bass (Micropterus salmoides) populations and (ii) the potential indirect effects of consumption by northern pike and largemouth bass predators on bluegill (Lepomis macrochirus) and yellow perch (Perca flavescens) prey populations. Future consumption by largemouth bass and northern pike may require a larger prey base to meet these demands (e.g. compensatory response) based on climate change projections. Primarily, we were interested in the magnitude (substantial or minimal) and direction (lower or higher) of change related to temperature rather than specific estimates of growth, consumption and predation effects because of future population dynamics uncertainties for these species (i.e. recruitment, mortality).
We focused our study on a shallow lake ecosystem that contained two dominant predators common in many systems in the USA (largemouth bass and northern pike) and two common prey species (bluegill and yellow perch) within the Sandhills region of north-central Nebraska. These systems were ideal for studying the effect of changing water temperatures. First, most lakes are very shallow (i.e. 2.9 m average maximum depth; McCarraher 1977; Paukert \& Willis 2000) and will respond much quicker to fluctuating temperatures than deeper lentic systems (Murdoch \& Power 2013). Second, fish assemblages are relatively simple (Paukert et al. 2002b), enabling more accurate interpretations of potential future effects because complex food webs and species interactions are minimized. Third, northern pike are at the southern edge of their native range in the Sandhills while largemouth bass are not (Page \& Burr 1991), offering an opportunity to compare two species with different thermal tolerances. Thus, we hypothesized that northern pike in these lakes will be most affected by water temperature increases that may exceed their optimal upper thermal limit and ultimately result in increased consumption to meet their metabolic demands (Casselman \& Lewis 1996). Alternatively, largemouth bass will likely be less affected by increases in temperature as water temperatures may increase towards their optimal growth temperature (Niimi \& Beamish 1974), followed by a slight increase in consumption and metabolism. We also expected greater predation pressure to be exerted on prey populations following these elevated changes in predator consumption rates, especially by northern pike.

\section{Methods}

\section{Study site}

West Long Lake is a 25-ha natural lake located on the Valentine National Wildlife Refuge in the Sandhills region of Cherry County, Nebraska, USA (Fig. 1). West Long Lake is a shallow eutrophic lake with a mean depth of $1.2 \mathrm{~m}$ and a maximum depth of $1.8 \mathrm{~m}$; the lake is dominated by submerged vegetation ( $80 \%$ surface area coverage) in mid-summer (Paukert \& Willis 2000) and is surrounded almost entirely by native grasslands (McCarraher 1977). The fish assemblage is relatively simple and includes largemouth bass, northern pike, bluegill, yellow perch and black bullhead (Ameiurus melas).

\section{Field and laboratory methods}

Largemouth bass $(N=334)$ and northern pike $(N=21)$ diets were assessed four times throughout the 2001 growing season (Table 1). Stomach contents 


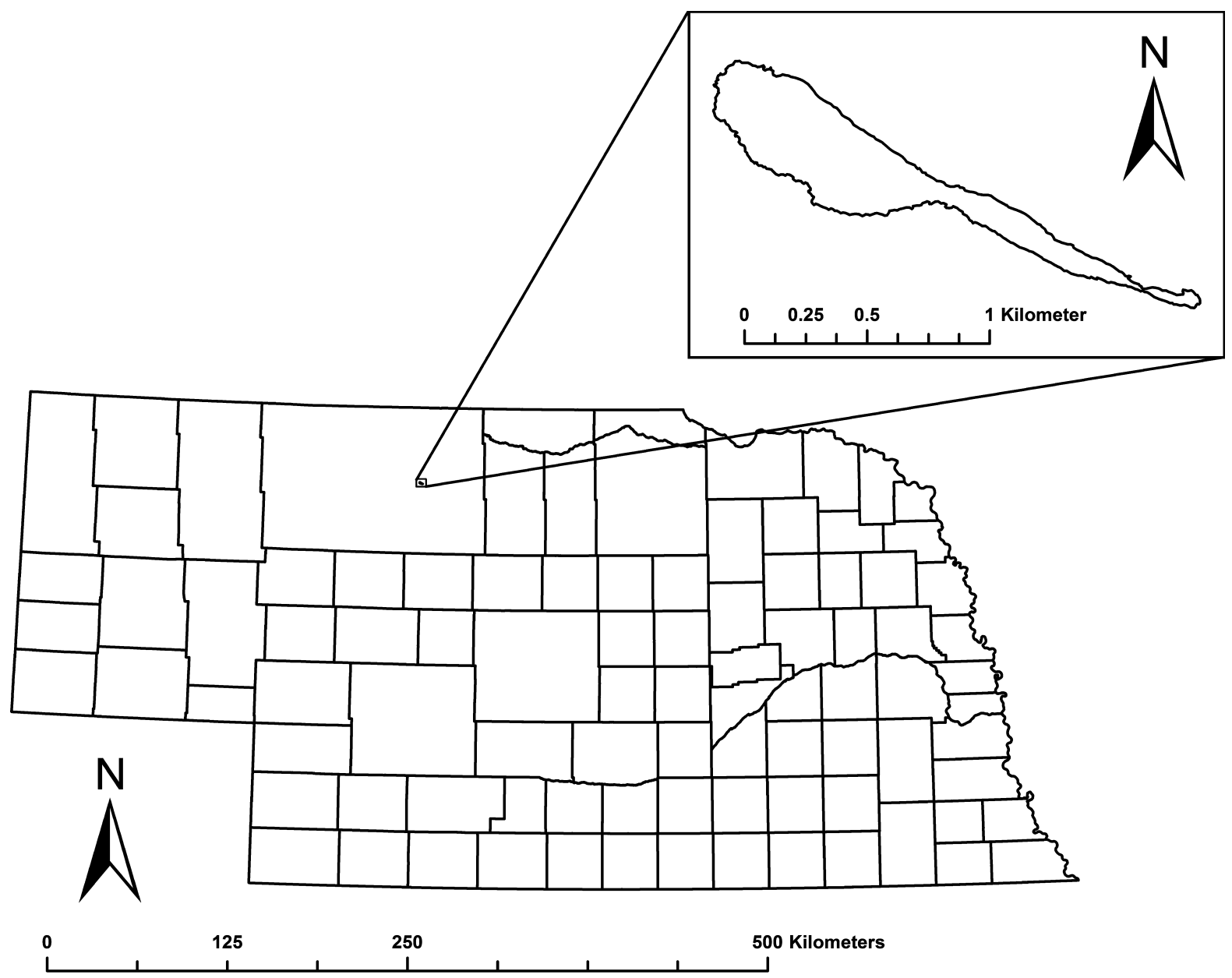

Fig. 1. State of Nebraska, USA (bottom left), and location of West Long Lake (upper right).

were collected April 18-24, June 19-21, August 5-6, and October 4, 7 and 15. Fish were collected using a combination of electrofishing and short-term gill net sets (Paukert et al. 2003). Stomach contents were extracted using acrylic tubes and gastric lavage (Light et al. 1983; Kamler \& Pope 2001). Diets were collected from two length categories of largemouth bass $(<300 \mathrm{~mm}$ and $>300 \mathrm{~mm}$, total length [TL]) and northern pike $(<400 \mathrm{~mm}$ and $>400 \mathrm{~mm}$, TL). Diet items were identified to the lowest possible taxonomic resolution (e.g. family for macroinvertebrates and species for fish) and summarized as per cent of diet taxa by wet weight. Caloric values of prey items were obtained from published reports (Cummins \& Wuycheck 1971; Kitchell et al. 1974; Craig 1977; Rice et al. 1983; Bevelheimer et al. 1985; Bryan et al. 1996).

Mark-recapture was used to estimate the number of largemouth bass and northern pike in West Long Lake. Schnabel multiple mark-recapture population estimates were used to estimate population size for both length categories of largemouth bass (May 22, 30, 31 and June 5-7, 2001) and northern pike (April
$2-8,2002)$. Northern pike were sampled and recaptured with modified fyke nets, and largemouth bass were collected and recaptured by night-time electrofishing. The left pectoral fin was clipped for both species, and lengths and weights were recorded for the first 100 fish of each species sampled to index size structure. For a more detailed description of the sampling methods used to estimate population size or biomass, see Paukert et al. (2002a) and DeBates (2003).

Direct effects on consumption and growth rates of predators

Potential effects of climate change on the fish assemblage in West Long Lake were assessed using bioenergetics models (Hanson 1997) to estimate largemouth bass and northern pike consumption and growth under observed and simulated temperature regimes. Water temperature was recorded every $2 \mathrm{~h}$ in 2001 for the duration of the study using a temperature logger placed at the centre of the lake $0.5 \mathrm{~m}$ below the surface. Because Sandhill lakes are 


\section{Breeggemann et al.}

Table 1. Sample sizes for bioenergetics modelling of largemouth bass (LMB) and northern pike (NOP) containing diet items by length categories during April, June, August and October 2001 (no samples '-' collected during May, July and September) in West Long Lake. Mean monthly predicted temperature changes $\left({ }^{\circ} \mathrm{C}\right)$ in Cherry County, Nebraska, during the years 2040 and 2060 according to three regional climate models (i.e. MPI, USGS and GFDL; Hostetler et al. 2011).

\begin{tabular}{|c|c|c|c|c|c|c|c|c|c|c|}
\hline \multirow[b]{3}{*}{ Month } & \multicolumn{4}{|c|}{ Sample sizes } & \multicolumn{6}{|c|}{ Mean monthly predicted temperature changes } \\
\hline & \multicolumn{2}{|l|}{ LMB } & \multicolumn{2}{|l|}{ NOP } & \multicolumn{3}{|l|}{2040} & \multicolumn{3}{|c|}{2060} \\
\hline & $<300 \mathrm{~mm}$ & $>300 \mathrm{~mm}$ & $<400 \mathrm{~mm}$ & $>400 \mathrm{~mm}$ & MPI & USGS & GFDL & MPI & USGS & GFDL \\
\hline April & 1 & 44 & 1 & 2 & 0.62 & -0.18 & -0.09 & 2.44 & 1.47 & 1.97 \\
\hline May & - & - & - & - & 1.23 & -0.10 & 1.34 & 3.03 & 1.31 & 3.06 \\
\hline June & 22 & 39 & 1 & 0 & 0.96 & 0.28 & 2.32 & 2.40 & 1.09 & 2.96 \\
\hline July & - & - & - & - & 0.96 & 0.94 & 2.07 & 2.34 & 2.84 & 3.36 \\
\hline August & 31 & 35 & 7 & 1 & 0.94 & 1.33 & 2.17 & 2.84 & 2.99 & 3.14 \\
\hline September & - & - & - & - & 1.73 & 0.77 & 1.96 & 2.50 & 2.10 & 1.73 \\
\hline October & 28 & 27 & 5 & 1 & 2.01 & 1.30 & 0.98 & 2.65 & 2.93 & 3.51 \\
\hline
\end{tabular}

polymictic, they do not typically stratify during summer months (Paukert \& Willis 2000). We used predicted 2040-49 and 2060-69 (hereafter 2040 and 2060 respectively) air temperatures from three climate models coupled with regional climate downscaling for Cherry County, Nebraska (Hostetler et al. 2011; Table 1), to simulate effects of climate change on consumption and growth of fish predators (i.e. MPI ECHAM5 - Roeckner et al. 2003; USGS GENMOM - Alder et al. 2010; GFDL CM2.0 - Delworth et al. 2006). Downscaled regional models provided the accuracy required for the simulations used for this study compared to global general circulation models (GCMs) that are more generalized and coarse in resolution. Therefore, each of the bioenergetics simulations described below was run three separate times to accommodate each climate change model, using predicted 2040 and 2060 temperature changes.

Predicted air temperatures from each of the climate models were used to simulate water temperatures observed in West Long Lake. As in other studies, we adjusted water temperature to account for corresponding changes in air temperature (Pine \& Allen 2001; Wuellner et al. 2010; Pease \& Paukert 2014); for example, if mean air temperature increased by $1{ }^{\circ} \mathrm{C}$, then we adjusted mean water temperature by $+1{ }^{\circ} \mathrm{C}$. Additionally, we examined empirical data from a nearby lake (i.e. Pelican Lake, NE, USA) with a similar morphometry and found a strong relationship between water temperatures and air temperatures during the 2010 and 2011 growing seasons (slope $=1.03 ; F_{1,414}=1.64, P=0.20, R^{2}=0.83$ ), thus providing additional support for our water temperature adjustments.

Diet information for largemouth bass and northern pike was used for bioenergetics simulations (Table 1). However, sample sizes were not sufficient to conduct bioenergetics simulations on age-specific cohorts, resulting in the use of two size categories per species. A natural break in length frequency distributions allowed for the separation of these length groups and minimized overlap (i.e. between size groups) in the modelling simulations (Paukert et al. 2002a; DeBates 2003). Bioenergetics modelling was used to evaluate two growth scenarios for each size group of fish predator; a 'no-growth' simulation based on maintenance consumption (i.e. no growth but metabolic demands were met) and a (probable growth' simulation based on empirical growth data for northern pike and largemouth bass. Both simulations were conducted using observed water temperatures in 2001 (i.e. baseline models), and predicted water temperatures in 2040, and 2060 (Table 2). Daily consumption throughout the growing season (April-October, Northern Hemisphere) and cumulative food consumption at the end of the growing sea-

Table 2. Summary of the bioenergetics simulations used to assess (i) direct effects on consumption and growth rates of predators (top) and (ii) indirect effects of consumption by predators on prey populations (bottom). No-growth models did not allow for growth, and only metabolic demands were satisfied. Probable growth models used $P$-values generated from the 2001 baseline models. Multiple response metrics were generated and evaluated for each climate change model (i.e. MPI, USGS and GFDL) during three separate time periods $(2001,2040,2060)$ where one variable in addition to temperature was manipulated (no growth, $P$-value) to assess climate change effects in West Long Lake.

\begin{tabular}{|c|c|c|c|}
\hline Simulation & Time period & $\begin{array}{l}\text { Variable } \\
\text { manipulated }\end{array}$ & $\begin{array}{l}\text { Response } \\
\text { metric }\end{array}$ \\
\hline \multicolumn{4}{|c|}{ Predator consumption and growth rates } \\
\hline No growth & $\begin{array}{l}2001 \text { (baseline); } \\
\text { 2040; } 2060\end{array}$ & No growth & $\begin{array}{l}\text { Daily consumption, } \\
\text { cumulative consumption }\end{array}$ \\
\hline $\begin{array}{l}\text { Probable } \\
\text { growth }\end{array}$ & $\begin{array}{l}2001 \text { (baseline); } \\
\text { 2040; } 2060\end{array}$ & $P$-value & Growth or final end weight \\
\hline \multicolumn{4}{|c|}{ Consumption of prey populations by predators } \\
\hline No growth & $\begin{array}{l}2001 \text { (baseline); } \\
\text { 2040; } 2060\end{array}$ & No growth & $\begin{array}{l}\text { Cumulative consumption, } \\
\text { per cent standing stock } \\
\text { consumed }\end{array}$ \\
\hline $\begin{array}{l}\text { Probable } \\
\text { growth }\end{array}$ & $\begin{array}{l}2001 \text { (baseline); } \\
\text { 2040; } 2060\end{array}$ & $P$-value & $\begin{array}{l}\text { Cumulative consumption, } \\
\text { per cent standing stock } \\
\text { consumed }\end{array}$ \\
\hline
\end{tabular}


son were assessed under the no-growth models. Furthermore, final weights at the end of the growing season were also recorded for the probable growth models (Table 2).

To examine changes in consumption related to climate change, a baseline model was constructed using temperatures recorded in 2001 and a no-growth estimate. Results from the baseline no-growth model were used to compare changes (\%) in daily and cumulative consumption under the predicted 2040 and 2060 temperature regimes, again using a nogrowth model. Mean monthly per cent change in daily consumption and per cent change in total cumulative consumption were calculated for largemouth bass and northern pike throughout the growing season (April-October). Growth rates were also estimated under probable growth scenarios for largemouth bass and northern pike. Probable growth increments of northern pike $\left(149 \mathrm{~g} \cdot \mathrm{y}^{-1}:<400 \mathrm{~mm}\right.$; $1151 \mathrm{~g} \cdot \mathrm{y}^{-1}:>400 \mathrm{~mm}$ ) were estimated from mean annual growth increments of eleven Sandhill northern pike populations during 1998 and 1999 (Paukert \& Willis 2000). Probable growth increments for largemouth bass $\left(177 \mathrm{~g} \cdot \mathrm{y}^{-1}: \quad<300 \mathrm{~mm} ; 466 \mathrm{~g} \cdot \mathrm{y}^{-1}\right.$ : $>300 \mathrm{~mm}$ ) were estimated from annual growth increments from West Long Lake (Paukert \& Willis 2000). Similar to the no-growth models, 2001 temperatures and the probable growth increments were used to develop baseline consumption models (Carey $\&$ Zimmerman 2014). $P$-values (per cent of maximum consumption) generated from baseline bioenergetics simulations (i.e. 2001 consumption) were held constant for largemouth bass and northern pike under the predicted 2040 and 2060 temperatures. Effects of warmer water temperature on growth of largemouth bass and northern pike were assessed by comparing the per cent change in final weight between 2001 and those predicted from the 2040 and 2060 temperature regimes.

Indirect effects of consumption by predators on prey populations

Bioenergetics simulations were used to examine the predatory effects of largemouth bass and northern pike on bluegill and yellow perch populations under different temperature scenarios in West Long Lake. Simulations were used to examine no growth and probable growth during the 2001 baseline, 2040 and 2060 temperature regimes (Table 2). For the 2040 and 2060 simulations, cumulative consumption of yellow perch and bluegill at the end of a growing season was used to calculate the per cent change in total consumption by the predator population (i.e. both size classes of northern pike and largemouth bass) compared to the 2001 baseline conditions (Table 2).

\section{Results}

Direct effects on consumption and growth rates of predators

Daily consumption by largemouth bass increased each month under the predicted 2040 and 2060 temperature models (Fig. 2). Average per cent change in daily consumption for both length categories of largemouth bass increased each month across the predicted 2040 and 2060 temperature models and ranged from 0.25 to $67.2 \%$ (Fig. 2). The greatest per cent increase in average daily consumption by largemouth bass typically occurred in the spring (April and May) and fall (September and October; Fig. 2). In contrast, estimates of average daily consumption by northern pike increased during April, May and June, decreased or remained nearly the same for July and August, and then increased again during September and October under the 2040 and 2060 temperature models (Fig. 2). Average per cent change in daily consumption by northern pike across the 2040 and 2060 temperature regimes ranged from -17.7 to $76.1 \%$ (Fig. 2).

Total food consumption by largemouth bass increased by approximately $5-15 \%$ under the predicted 2040 temperature models and approximately 20-30\% under the predicted 2060 models (Fig. 3). Similarly, total consumption by northern pike increased by approximately $4-13 \%$ under the predicted 2040 temperature models and approximately 14-24\% under the predicted 2060 models (Fig. 3). The per cent change in mean daily and total food consumption was greater under the predicted 2060 temperature models compared to the 2040 models for both largemouth bass and northern pike (Figs 2 and 3).

Bioenergetics simulations resulted in different growth outcomes for both length categories of largemouth bass under 2040 temperature models $(\mathrm{MPI}=$ gain weight; $\quad$ USGS and $\mathrm{GFDL}=$ lose weight; Fig. 4). However, changes in predicted final weights for both size categories of largemouth bass in 2040 were small compared to 2001 predicted final weights, ranging from a -1.3 to a $4.3 \%$ difference (Fig. 4). Furthermore, the 2060 temperature models predicted the small size category of largemouth bass to gain weight $(1.7 \%)$ according to the MPI model but lose weight in both USGS $(-5.1 \%)$ and GFDL $(-6.4 \%)$ climate models (Fig. 4). The large size category of largemouth bass lost weight by the end of the growing season under all 2060 temperature models, with final weights ranging from -0.1 to $-4.1 \%$ (Fig. 4). In contrast, northern pike had lower final weights by the end of the growing season under all the 2040 and 2060 temperature models (Fig. 4). The 


\section{Breeggemann et al.}

per cent differences in final weights between the 2001 temperature model and the 2040 and 2060 temperature models ranged from -3.3 to $-27.5 \%$ and -17.7 to $-45.3 \%$, respectively, for northern pike (Fig. 4).

Indirect effects of consumption by predators on prey populations

The largemouth bass population in West Long Lake in June 2001 was estimated at 2047 fish (95\% confidence interval: 1670-2545); 22\% (450 largemouth bass) were $<300 \mathrm{~mm}$ and $78 \%$ (1597 largemouth bass) were $>300 \mathrm{~mm}$ (TL range: $125-550 \mathrm{~mm}$ ). The northern pike population in West Long Lake in April 2002 was estimated at 909 fish $(95 \%$ confidence interval: 720-1180); 56\% (509 northern pike) were $<400 \mathrm{~mm}$ and $44 \%$ (400 northern pike) were $>400 \mathrm{~mm}$ (TL range: $250-750 \mathrm{~mm}$ ).
Using the no-growth scenario, total consumption of bluegill $\left(\mathrm{kg} \cdot \mathrm{ha}^{-1}\right)$ by all predators increased by approximately $8-18 \%$ under predicted 2040 temperature models and increased by $22-24 \%$ under predicted 2060 temperature models, compared to the 2001 baseline consumption model (Table 3). Under the probable growth scenario, largemouth bass and northern pike total consumption $\left(\mathrm{kg} \cdot \mathrm{ha}^{-1}\right)$ of bluegill increased by $7-13 \%$ under predicted 2040 temperature models and increased approximately 16-17\% under predicted 2060 temperature models (Table 3).

Again using the no-growth scenario, total consumption $\left(\mathrm{kg} \cdot \mathrm{ha}^{-1}\right)$ of yellow perch by largemouth bass and northern pike increased by approximately 5-14\% under predicted 2040 temperature models and increased by about $17-23 \%$ under predicted 2060 temperature models, compared to the 2001 baseline model (Table 3). Under the probable growth scenario, largemouth bass and northern pike total

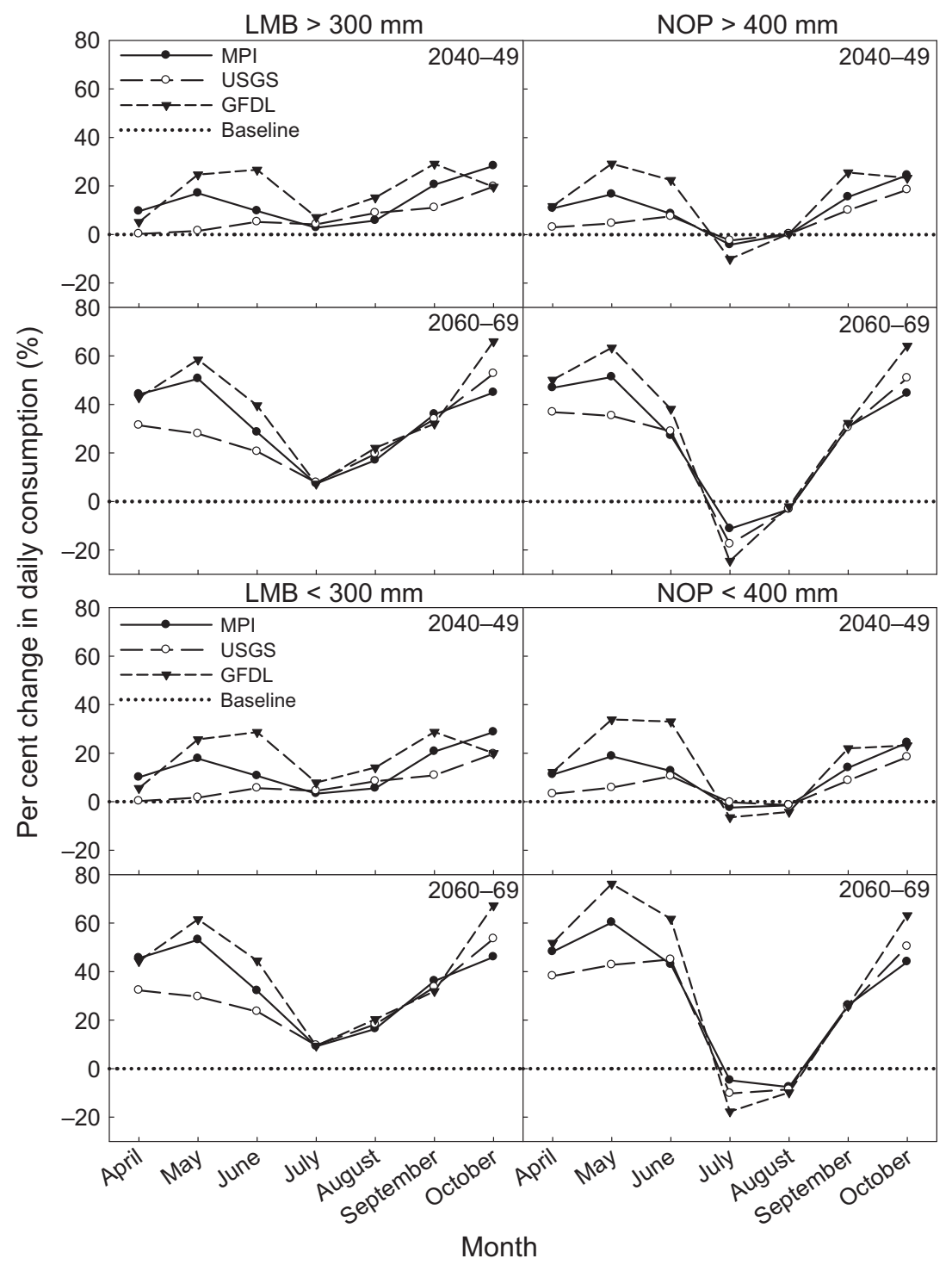

Fig. 2. Mean per cent change in daily consumption by month for two length categories of largemouth bass (LMB; $>300 \mathrm{~mm}$, upper left; $<300 \mathrm{~mm}$, lower left) and northern pike (NOP; $>400 \mathrm{~mm}$, upper right; $<400 \mathrm{~mm}$, lower right) modelled under projected 2040 and 2060 water temperatures from three different climate change models (i.e. MPI, USGS, and GFDL) compared to 2001 water temperatures (baseline) in West Long Lake, Nebraska. 


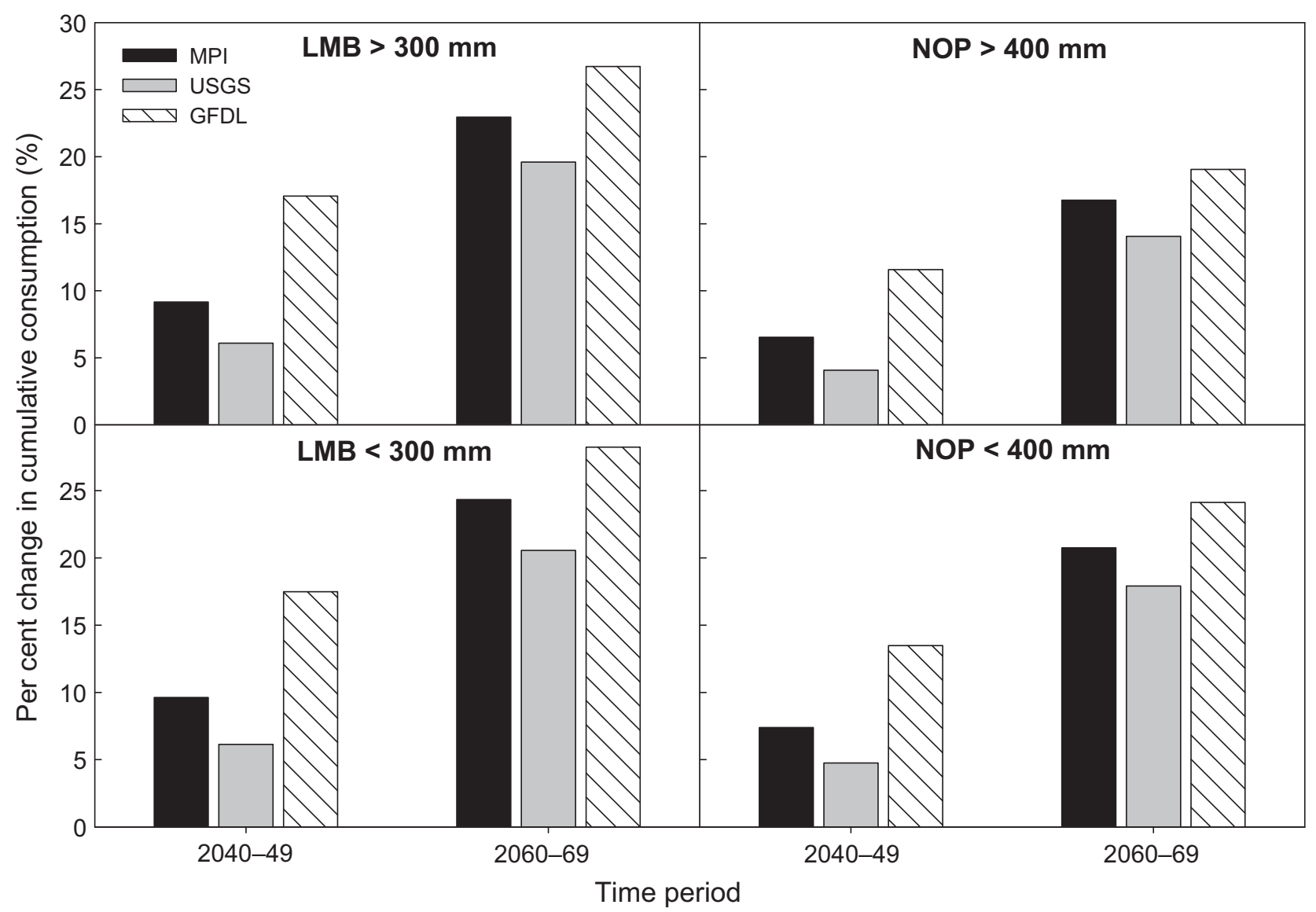

Fig. 3. Per cent change in cumulative consumption for two length categories of largemouth bass (LMB; $>300 \mathrm{~mm}$ and $<300 \mathrm{~mm})$ and northern pike (NOP; $>400 \mathrm{~mm}$ and $<400 \mathrm{~mm}$ ) modelled under projected 2040 and 2060 water temperatures from three different climate change models (i.e. MPI, USGS, and GFDL) compared to 2001 water temperatures (baseline) in West Long Lake, Nebraska.

consumption $\left(\mathrm{hg} \cdot \mathrm{ha}^{-1}\right.$ ) of yellow perch increased by approximately $3-10 \%$ under predicted 2040 temperature models and increased by about $12-16 \%$ under predicted 2060 temperature models (Table 3).

\section{Discussion}

The change in daily and total consumption between largemouth bass and northern pike was not as pronounced as expected. While both species generally consumed substantially more under warmer climate scenarios, the magnitude and patterns were quite similar despite different species-specific thermal tolerances and optimums (Coutant \& Cox 1976; Casselman 1978; Pierce 2012), and despite the fact that northern pike are at the southern edge of their range and largemouth bass are not (Page \& Burr 1991). One major difference was found during the summer months (i.e. July and August) when northern pike consumed less than they did in 2001 compared to largemouth bass; but overall, both species will likely require a greater annual supply of prey. Patterns in daily consumption also revealed a temporal aspect that is equally as important as the magnitude and direction of overall consumption. Durant et al. (2007) explored this relationship in greater detail and exposed critical phenology mismatches between reproductive processes and predator-prey relationships that are unlikely to align with climate change. Our study suggested that much higher prey demands will be anticipated for largemouth bass and northern pike during the fall (September and October) and spring (April and May) compared to 2001 estimates. Not only will an increase in prey be required for these two predators but the timing of prey availability will be critical, particularly because predation pressure on bluegill and yellow perch populations is already high in these systems (Paukert et al. 2003). Increased recruitment and production of both prey species will be necessary to sustain largemouth bass and northern pike populations.

Feeding and growth of northern pike were predicted to respond to climate change to a greater extent than largemouth bass because Sandhill lakes are located near the southern edge of the northern pike's range (Page \& Burr 1991). Largemouth bass 


\section{Breeggemann et al.}

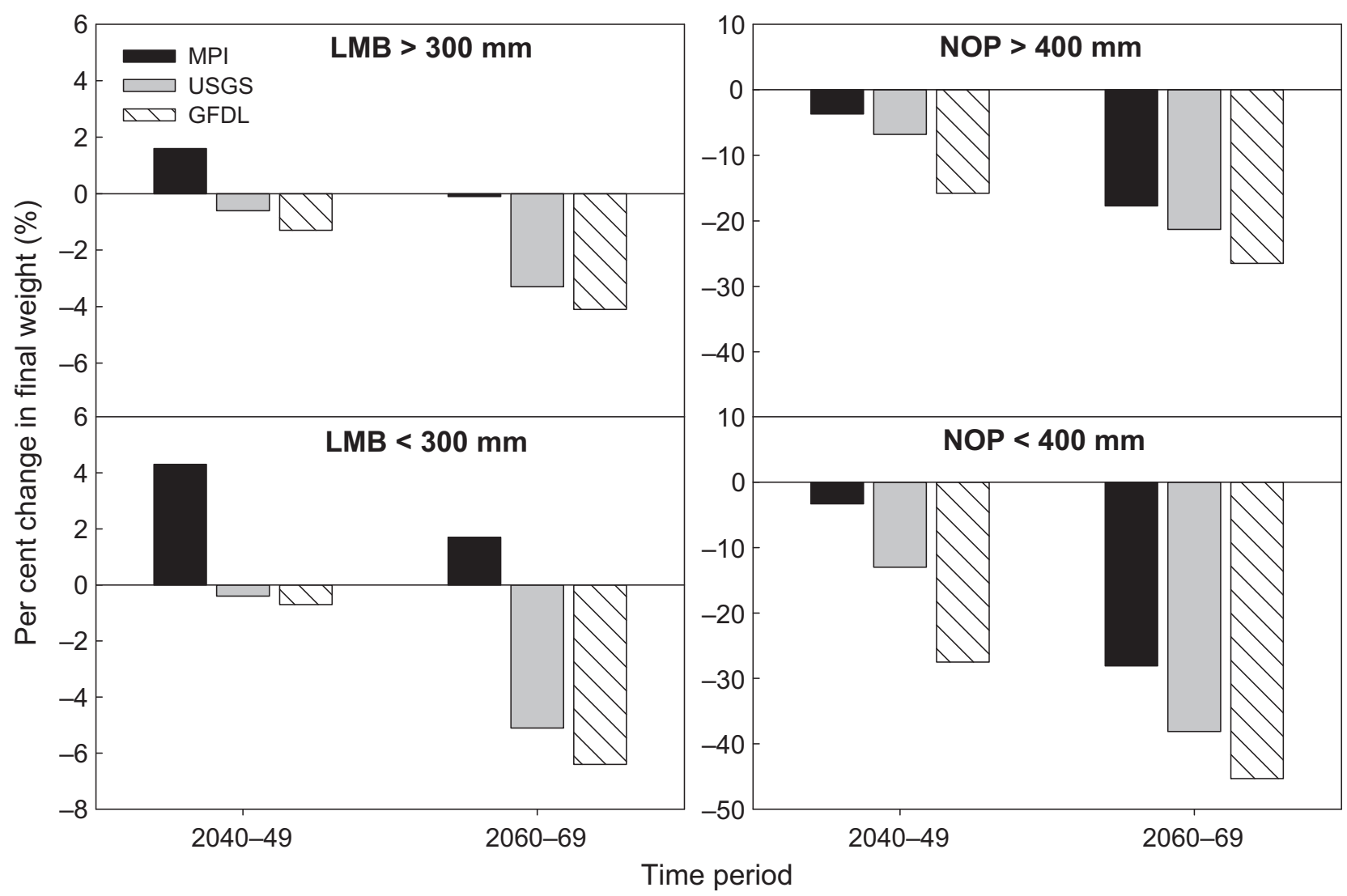

Fig. 4. Per cent change in final weight for two length categories of largemouth bass (LMB; $>300 \mathrm{~mm}$ and $<300 \mathrm{~mm}$ ) and northern pike (NOP; $>400 \mathrm{~mm}$ and $<400 \mathrm{~mm}$ ) modelled under projected 2040 and 2060 water temperatures from three different climate change models (i.e. MPI, USGS and GFDL) compared to 2001 water temperatures (baseline) in West Long Lake, Nebraska.

did not experience much difference in final weight, whereas northern pike suffered weight loss under elevated temperatures and in some cases (i.e. small size classes - 2060) over 30\%. Northern pike are a coolwater fish with an optimum growth temperature range of 20-24 ${ }^{\circ} \mathrm{C}$ (Pierce 2012). In 2001, water temperatures in West Long Lake surpassed this range during July and August, as well as portions of June and September (Fig. 5). Additionally, West Long Lake is a shallow, polymictic lake that has no summer thermal stratification, and thus no thermal refuge for large northern pike (Paukert \& Willis 2000). Growth rates and condition of northern pike in West Long Lake are already lower than their northern counterparts (Paukert \& Willis 2003), and future increases in water temperature will likely exacerbate limitations on growth potential. Other studies have revealed range limitations and habitat shifts for several species due to temperature or climate change (Christie \& Regier 1988; Perry et al. 2005). In contrast, largemouth bass are a warmwater fish with an optimum growth temperature range of $26-28{ }^{\circ} \mathrm{C}$ (Coutant \& Cox 1976). In 2001, water temperatures in West Long Lake reached this range for about a month from July to August (Fig. 5). However, the projected tem- peratures for 2040 predict that water temperatures will enter this range about 2 weeks earlier, near the end of June (Fig. 5). Therefore, water temperatures in 2040 may be more optimal for largemouth bass growth resulting in the slight increase in growth observed during that decade. Increased growth rates have been predicted for other species that may experience elevated water temperatures compared to current conditions (King et al. 1999; Pease \& Paukert 2014). Under projected 2060 temperatures, water temperatures will exceed optimal thermal largemouth bass conditions for about a month from July to August, resulting in reduced growth compared to 2001. The decrease in growth rates for largemouth bass during 2060 compared to the more recent time period was not nearly as extreme as it was for northern pike.

Largemouth bass growth was minimally influenced by changes in water temperature whereas northern pike were moderately influenced by 2040 modifications in temperature regimes and influenced even more by 2060 temperatures. Northern pike gained less weight in both time periods compared to the 2001 model. Decreased growth of northern pike could result in an alteration of maturation rates, 
Fish assemblage climate change effects

Table 3. Estimated consumption (kg.ha ${ }^{-1}$ ) of bluegill and yellow perch by two length categories of largemouth bass (LMB) and northern pike (NOP) based on no growth (left) and probable growth (right) simulations in 2001 and predicted 2040 and 2060 water temperatures from three different climate change models (i.e. MPI, USGS, and GFDL) in West Long Lake, Nebraska. No bluegill were consumed by LMB $<300 \mathrm{~mm}$ total length or NOP $>400 \mathrm{~mm}$ total length. Total consumption $\left(\mathrm{kg} \cdot \mathrm{ha}^{-1}\right)$ and the per cent change in total consumption (i.e. consumption by all predators) under all predicted future temperature scenarios.

\begin{tabular}{|c|c|c|c|c|c|c|c|c|}
\hline & \multicolumn{4}{|c|}{ No growth } & \multicolumn{4}{|c|}{ Probable growth } \\
\hline & 2001 & MPI & USGS & GFDL & 2001 & MPI & USGS & GFDL \\
\hline \multicolumn{9}{|l|}{ Bluegill } \\
\hline \multicolumn{9}{|l|}{2040} \\
\hline LMB >300 mm & 4.9 & 5.5 & 5.4 & 5.8 & 8.6 & 9.3 & 9.2 & 9.7 \\
\hline $\mathrm{NOP}<400 \mathrm{~mm}$ & 0.1 & 0.1 & 0.1 & 0.1 & 0.8 & 0.9 & 0.9 & 0.9 \\
\hline Total consumption & 5.0 & 5.5 & 5.4 & 5.9 & 9.4 & 10.2 & 10.1 & 10.6 \\
\hline Change in consumption (\%) & NA & 10.0 & 8.0 & 18.0 & NA & 8.5 & 7.4 & 12.8 \\
\hline \multicolumn{9}{|l|}{2060} \\
\hline LMB $>300 \mathrm{~mm}$ & 4.9 & 6.1 & 6.1 & 6.1 & 8.6 & 9.9 & 10.1 & 10 \\
\hline $\mathrm{NOP}<400 \mathrm{~mm}$ & 0.1 & 0.1 & 0.1 & 0.1 & 0.8 & 1.0 & 1.0 & 1.0 \\
\hline Total consumption & 5.0 & 6.1 & 6.2 & 6.2 & 9.4 & 10.9 & 11.1 & 11.0 \\
\hline Change in consumption (\%) & NA & 22.0 & 24.0 & 24.0 & $N A$ & 16.0 & 18.1 & 17.0 \\
\hline \multicolumn{9}{|l|}{ Yellow perch } \\
\hline \multicolumn{9}{|l|}{2040} \\
\hline LMB <300 mm & 1.5 & 1.6 & 1.6 & 1.8 & 3.8 & 4.0 & 4.0 & 4.1 \\
\hline LMB >300 mm & 24.9 & 27.6 & 26.4 & 29.4 & 41.0 & 44.1 & 42.7 & 46.1 \\
\hline $\mathrm{NOP}<400 \mathrm{~mm}$ & 0.7 & 0.7 & 0.7 & 0.8 & 4.7 & 4.8 & 4.7 & 4.9 \\
\hline $\mathrm{NOP}>400 \mathrm{~mm}$ & 48.2 & 51.4 & 50.2 & 53.8 & 78.9 & 82.7 & 81.3 & 85.7 \\
\hline Total consumption & 75.3 & 81.3 & 78.9 & 85.8 & 128.4 & 135.5 & 132.6 & 140.7 \\
\hline Change in consumption (\%) & NA & 8.0 & 4.8 & 13.9 & NA & 5.5 & 3.3 & 9.6 \\
\hline \multicolumn{9}{|l|}{2060} \\
\hline LMB $<300$ mm & 1.5 & 1.8 & 1.8 & 1.8 & 3.8 & 4.2 & 4.2 & 4.2 \\
\hline LMB >300 mm & 24.9 & 31.7 & 30.4 & 32.6 & 41.0 & 48.8 & 47.3 & 49.9 \\
\hline $\mathrm{NOP}<400 \mathrm{~mm}$ & 0.7 & 0.9 & 0.8 & 0.9 & 4.7 & 5.1 & 5.0 & 5.1 \\
\hline $\mathrm{NOP}>400 \mathrm{~mm}$ & 48.2 & 56.3 & 55.0 & 57.4 & 78.9 & 88.8 & 87.2 & 90.1 \\
\hline Total consumption & 75.3 & 90.6 & 88.0 & 92.8 & 128.4 & 146.9 & 143.6 & 149.3 \\
\hline Change in consumption (\%) & NA & 20.3 & 16.9 & 23.2 & NA & 14.4 & 11.8 & 16.3 \\
\hline
\end{tabular}

fecundity and overall fitness (Roff 1984; Shuter \& Meisner 1992). Climate change could also affect recruitment and egg development (Straile et al. 2007; Karjalainen et al. 2014). Provided that overall population dynamics become altered (recruitment, growth, and mortality; Dudgeon et al. 2006), consequences of increased temperatures for northern pike in the Nebraska Sandhills could extend to the entire fish assemblage because of their primary predatory role in these systems (Paukert \& Willis 2003). Therefore, largemouth bass could become the primary predator in many of these systems if northern pike cannot tolerate expected temperatures or find thermal refuge. According to estimated consumption rates, this would benefit yellow perch populations as northern pike consumed nearly twice the amount of yellow perch compared to largemouth bass. Community-level impacts could be mediated through temperature shifts that directly affect predator consumption rates and growth but indirectly affect prey populations via changes in predation pressure (Jeppesen et al. 2010). Climate change may therefore lead to future Sandhill fish communities that are dominated by largemouth bass and smaller populations of bluegill (increased

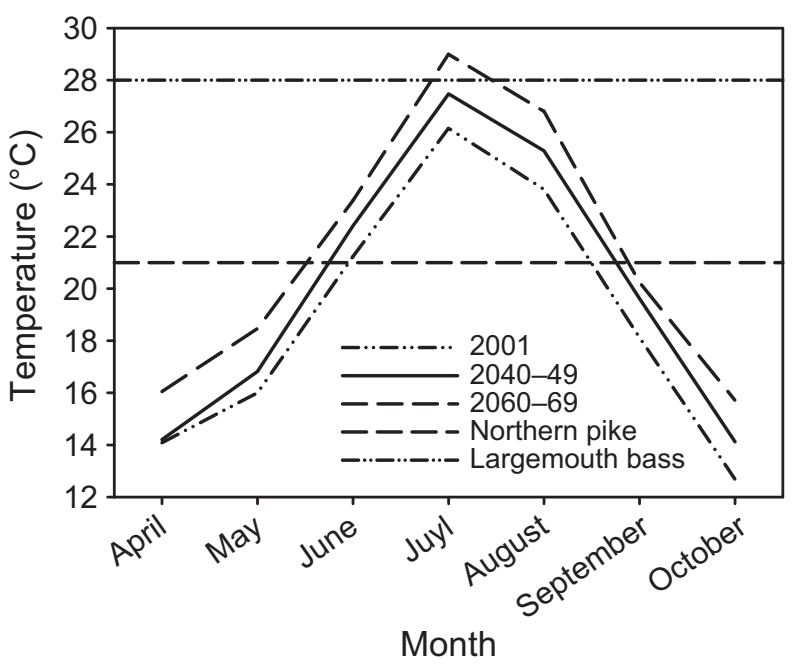

Fig. 5. Mean monthly water temperatures $\left({ }^{\circ} \mathrm{C}\right)$ during 2001 , and projected 2040 and 2060. Temperature averages across each climate change model (i.e. MPI, USGS and GFDL) are given for graphing simplicity and clarity, rather than depicting each model separately (as conducted in the analyses). Thermal optimum growth temperatures are also shown as horizontal reference lines for largemouth bass and northern pike (Coutant \& Cox 1976; Pierce 2012). 


\section{Breeggemann et al.}

predation by largemouth bass) and larger populations of yellow perch (predation release from northern pike - but see Discussion on temporal shifts in consumption and competitive interactions between prey species).

The potential for competition between northern pike and largemouth bass for available prey (e.g. yellow perch) could become an important factor to consider in the future (Lehtonen 1996). We postulate that largemouth bass would be favoured in this case as northern pike already exhibit poor condition and could experience shortages in preferred prey items (i.e. yellow perch) (Paukert \& Willis 2003). Yellow perch and bluegill populations are critically important for largemouth bass and northern pike in the Nebraska Sandhills (Paukert et al. 2002b, 2003; DeBates et al. 2003; Jolley et al. 2008), as evident by the current and future contribution to overall consumption and growth. Other studies have identified the significance of yellow perch and bluegill as prey for both of these species across their geographic range and in more diverse fish assemblages that could offer other foraging options (Seaburg \& Moyle 1964; Post \& Prankevicius 1987; Olson 1996). Assuming predator populations remain similar, it is possible that prey fish biomass could meet the consumption demands of both predators so long as their populations show a congruent (i.e. compensatory) response to increased water temperature; in this case, combined biomass of bluegill and yellow perch would need to increase by up to $24 \%$ compared to observed conditions.

Recruitment dynamics and year-class strength can vary for both species in Sandhill lakes but are more consistent than other systems containing bluegill and yellow perch (Kaemingk et al. 2014a,b). Although annual consumption demands may not have increased substantially for either species (always $<30 \%$ ), a shift occurred in the timing of when prey is required to meet these consumptive demands, especially for northern pike. Subtle changes and shifts in timing of consumption for northern pike and largemouth bass may influence how much prey is available (e.g. spring vs. summer feeding) and the overall impact it has on prey populations. Elevated predation pressure during spring when yellow perch are spawning could affect yellow perch recruitment as juveniles are much smaller and more vulnerable to predation (Sogard 1997). Predation intensity could remain high well into the fall season for both species (i.e. focusing more on late-hatched bluegill populations), and this may create a unique scenario as most bluegill recruitment is generated from late hatching individuals in a Nebraska Sandhill lake (Kaemingk et al. 2014b), further impacting long-term bluegill population structure and dynamics, but may also provide a source of prey in the fall for these predators. Future research is needed to examine how shifting predation pressure and consumption at different times of the year could alter fish assemblage dynamics. Additionally, accounting for potential growth and elevated consumption during other seasons (i.e. winter) should be explored as optimal temperatures could extend beyond typical growing seasons (i.e. spring, summer, and fall) for many species.

Our study highlighted several important aspects of how climate change may affect warm-water fish communities in shallow lakes. Growth of northern pike and largemouth bass varied among climate warming scenarios owing to differences in optimal metabolic temperatures between species. Because West Long Lake is near the southern extent of the northern pike's natural range, a warming climate had relatively larger impacts on growth rate of northern pike compared to largemouth bass. Thus, the effects of climate change on predator energy demands extend to predation on prey fishes resulting in increased and perhaps differential predation pressure on prey populations. Moreover, climate change may lead to a shift in the timing of predator-prey interactions which could lead to a shift in fish assemblage structure and dynamics within shallow lake ecosystems.

\section{Acknowledgements}

We thank Darrell Hartman and Doug Graham for logistical support, Greg Hesse, Mark Staab, Jerry Ryschong, Joel Klammer, and Andrew Glidden for helping to conduct the 2001 and 2002 population estimates. We also thank K. Pope for providing valuable comments and criticisms on earlier versions of this manuscript. Valentine National Wildlife Refuge (U.S. Fish and Wildlife Service) allowed access to West Long Lake. Phil Chvala, Howard Fullhart and Josh Smith provided assistance with field work. We also thank Dan Isermann for providing laboratory assistance. K. J. Stahr provided the map of West Long Lake. Funding for this project was provided by Nebraska Game and Parks Commission, Sport Fish Restoration Project Number F-118-R administered through South Dakota State University. The Missouri Cooperative Fish and Wildlife Research Unit is jointly sponsored by the Missouri Department of Conservation, the University of Missouri, the U.S. Geological Survey, the U.S. Fish and Wildlife Service and the Wildlife Management Institute. The South Dakota Cooperative Fish and Wildlife Research Unit is jointly supported by the U.S. Geological Survey, South Dakota State University, South Dakota Department of Game, Fish, and Parks, and the Wildlife Management Institute. The use of trade names or products does not constitute endorsement by the U.S. Government.

\section{References}

Alder, J.R., Hostetler, S.W., Pollard, D. \& Schmitter, A. 2010. Evaluation of a present-day climate simulation with a new 
atmosphere-ocean model GENMOM. Geoscientific Model Development 3: 69-83.

Bevelheimer, M.S., Stein, R.A. \& Carline, R.F. 1985. Assessing significance of physiological differences among three esocids with a bioenergefics model. Canadian Journal of Fisheries and Aquatic Sciences 42: 57-69.

Biro, P.A., Post, J.R. \& Booth, D.J. 2007. Mechanisms for climate-induced mortality of fish populations in whole-lake experiments. Proceedings of the National Academy of Sciences of the United States of America 104: 9715-9719.

Brandt, S.B., Mason, D.M., McCormick, M.J., Lofgren, B., Hunter, T.S. \& Tyler, J.A. 2002. Climate change: implications for fish growth performance in the Great Lakes. Proceedings of the American Fisheries Society Symposium: 61-76.

Brown, J.H., Gillooly, J.F., Allen, A.P., Savage, V.M. \& West, G.B. 2004. Toward a metabolic theory of ecology. Ecology 85: 1771-1789.

Bryan, S.D., Soupir, C.A., Duffy, W.G. \& Freiburger, C.E. 1996. Caloric densities of three predatory fishes and their prey in Lake Oahe, South Dakota. Journal of Freshwater Ecology 11: 153-161.

Carey, M.P. \& Zimmerman, C.E. 2014. Physiological and ecological effects of increasing temperature on fish production in lakes of Arctic Alaska. Ecology and Evolution 4: 1981-1993.

Casselman, J.M. 1978. Effects of environmental factors on growth, survival, activity, and exploitation of northern pike. In: Kendall, R.L., ed. Selected coolwater fishes of North America. Bethesda, Maryland: American Fisheries Society Special Publication 11, pp. 114-128.

Casselman, J.M. 2002. Effects of temperature, global extremes, and climate change on year-class production of warmwater, coolwater, and coldwater fishes in the Great Lakes basin. Proceedings of the American Fisheries Society Symposium: 39-60.

Casselman, J.M. \& Lewis, C.A. 1996. Habitat requirements of northern pike (Essox lucius). Canadian Journal of Fisheries and Aquatic Sciences 53: 161-174.

Chipps, S.R. \& Wahl, D.H. 2008. Bioenergetics modeling in the 21st century: reviewing new insights and revisiting old constraints. Transactions of the American Fisheries Society 137: $298-313$.

Christie, G.C. \& Regier, H.A. 1988. Measures of optimal thermal habitat and their relationship to yields for four commercial fish species. Canadian Journal of Fisheries and Aquatic Sciences 45: 301-314.

Coutant, C.C. \& Cox, D.K. 1976. Growth rates of subadult largemouth bass at 24 to 35.5 C. Proceedings of the Thermal Ecology II, Augusta, Georgia, USA.

Craig, J. 1977. The body composition of adult perch, Perca fluviatilis in Windermere, with reference to seasonal changes and reproduction. The Journal of Animal Ecology 46: 617632.

Cummins, K.W. \& Wuycheck, J.C. 1971. Caloric equivalents for investigations in ecological energetics. Stuttgart, Germany: International Association of Theoretical and Applied Limnology.

DeBates, T.J. 2003. Predator-prey interactions of fishes in two Nebraska Sandhill lakes. Wildlife and Fisheries Sciences Department, South Dakota State University, M.Sc. Thesis.
DeBates, T.J., Paukert, C.P. \& Willis, D.W. 2003. Fish community responses to the establishment of a piscivore, northern pike (Esox lucius), in a Nebraska Sandhill lake. Journal of Freshwater Ecology 18: 353-359.

Delworth, T.L., Broccoli, A.J., Rosati, A., Stouffer, R.J., Balaji, V., Beesely, J.A., Cooke, W.F., Dixon, K.W., Dunne, J., Dunne, K.A., Durachta, J.W., Findell, K.L., Ginoux, P., Gnanadesikan, A., Gordon, C.T., Griffies, S.M., Gudgel, R., Harrison, M.J., Held, I.M., Hemler, R.S., Horowitz, L.W., Klein, S.A., Knutson, T.R., Kushner, P.J., Langenhorst, A.R., Lee, H., Lin, S., Lu, J., Malyshev, S.L., Milly, P.C.D., Ramaswamy, V., Russell, J., Schwarzkopf, M.D., Shevliakova, E., Sirutis, J.J., Spelman, M.J., Stern, W.F., Winton, M., Wittenberg, A.T., Wyman, B., Zeng, F. \& Zhang, R. 2006. GFDL's CM2 global coupled climate models. Part 1: formulation and simulation characteristics. Journal of Climate 19: 643-674.

Dudgeon, D., Arthington, A.H., Gessner, M.O., Kawabata, Z.-I., Knowler, D.J., Lévêque, C., Naiman, R.J., Prieur-Richard, A.H., Soto, D., Stiassny, M.L.J.\& Sullivan, C.A. 2006. Freshwater biodiversity: importance, threats, status and conservation challenges. Biological Reviews 81: 163-182.

Durant, J.M., Hjermann, D.Ø. \& Stenseth, N.C. 2007. Climate and the match or mismatch between predator requirements and resource availability. Climate Research 33: 271-283.

Hanson, P.C. 1997. Fish bioenergetics 3.0 for Windows. Madison, WI: University of Wisconsin Sea Grant Institute.

Hill, D.K. \& Magnuson, J.J. 1990. Potential effects of global climate warming on the growth and prey consumption of Great Lakes fish. Transactions of the American Fisheries Society 119: 265-275.

Hostetler, S.W., Alder, J.R. \& Allan, A.M. 2011. Dynamically downscaled climate simulations over North America: Methods, evaluation, and supporting documentation for users: U.S. Geological Survey Open-File Report 2011-1238, U.S. Geological Survey, Reston, Virginia.

Jeppesen, E., Meerhoff, M., Holmgren, K., Gonzales-Bergonzoni, I., Teixeira-de Mello, F., Declerck, S.A.J., De Meester, L., Søndergaard, M., Lauridsen, T.L., Bjerring, R., CondePorcuna, J.M., Mazzeo, N., Iglesias, C., Reizenstein, M., Malmquist, H.J., Liu, Z., Balayla, D. \& Lazzaro, X. 2010. Impacts of climate warming on lake fish community structure and potential effects on ecosystem function. Hydrobiologia 646: 73-90.

Johnson, B.M., Martinez, P.J., Hawkins, J.A. \& Bestgen, K.R. 2008. Ranking predatory threats by nonnative fishes in the Yampa River, Colorado, via bioenergetics modeling. North American Journal of Fisheries Management 28: 1941-1953.

Jolley, J.C., Willis, D.W., Debates, T.J. \& Graham, D.D. 2008. The effects of mechanically reducing northern pike density on the sport fish community of West Long Lake, Nebraska, USA. Fisheries Management and Ecology 15: 251-258.

Kaemingk, M.A., Graeb, B.D.S. \& Willis, D.W. 2014a. Temperature, hatch date, and prey availability influence age-0 yellow perch growth and survival. Transactions of the American Fisheries Society 143: 845-855.

Kaemingk, M.A., Stahr, K.J., Jolley, J.C., Holland, R.S. \& Willis, D.W. 2014b. Evidence for bluegill spawning plasticity obtained by disentangling complex factors related to 


\section{Breeggemann et al.}

recruitment. Canadian Journal of Fisheries and Aquatic Sciences 71: 93-105.

Kamler, J.F. \& Pope, K.L. 2001. Nonlethal methods of examining fish stomach contents. Reviews in Fisheries Science 9: $1-11$.

Karjalainen, J., Keskinen, T., Pulkkanen, M. \& Marjomäki, T.J. 2014. Climate change alters the egg development dynamics in cold-water adapted coregonids. Environmental Biology of Fishes 98: 979-991. doi:10.1007/s10641-0140331-y.

King, J.R., Shuter, B.J. \& Zimmerman, A.P. 1999. Empirical links between thermal habitat, fish growth, and climate change. Transactions of the American Fisheries Society 128: 656-665.

Kitchell, J.F., Koonce, J.F., Magnuson, J.J., O’Neill, R.V., Herman, H., Shugart, J.R. \& Booth, R.S. 1974. Model of fish biomass dynamics. Transactions of the American Fisheries Society 103: 786-798.

Lehtonen, H. 1996. Potential effects of global warming on northern European freshwater fish and fisheries. Fisheries Management and Ecology 3: 59-71.

Light, R.W., Adler, P.H. \& Arnold, D.E. 1983. Evaluation of gastric lavage for stomach analyses. North American Journal of Fisheries Management 3: 81-85.

Magnuson, J.J. 2001. A future of adapting to climate change and variability. Fisheries in a Changing Climate 32: 273-282.

Magnuson, J.J., Crowder, L.B. \& Medvick, P.A. 1979. Temperature as an ecological resource. American Zoologist 19: 331-343.

McCarraher, D.B. 1977. Nebraska's Sandhills lakes. Lincoln, NE: Nebraska Game and Parks Commission.

McCarthy, S.G., Duda, J.J., Emlen, J.M., Hodgson, G.R. \& Beauchamp, D.A. 2009. Linking habitat quality with trophic performance of steelhead along forest gradients in the South Fork Trinity River Watershed, California. Transactions of the American Fisheries Society 138: 506-521.

Murdoch, A. \& Power, M. 2013. The effect of lake morphometry on thermal habitat use and growth in Arctic charr populations: implications for understanding climate-change impacts. Ecology of Freshwater Fish 22: 453-466.

Niimi, A. \& Beamish, F. 1974. Bioenergetics and growth of largemouth bass (Micropterus salmoides) in relation to body weight and temperature. Canadian Journal of Zoology 52: 447-456.

Olson, M.H. 1996. Predator-prey interactions in size-structured fish communities: implications of prey growth. Oecologia 108: 757-763.

Page, L.M. \& Burr, B.M. 1991. A field guide to freshwater fishes: North America north of Mexico. Boston, Massachusetts: Houghton Mifflin Harcourt.

Paukert, C. \& Willis, D. 2000. Factors affecting panfish populations in Sandhill lakes. Nebraska Game and Parks Commission, Federal Aid in Sport Fish Restoration Project F-118-R, Job 1.

Paukert, C.P. \& Willis, D.W. 2003. Population characteristics and ecological role of northern pike in shallow natural lakes in Nebraska. North American Journal of Fisheries Management 23: 313-322.

Paukert, C., DeBates, T. \& Willis, D. 2002a. Food habits of fish in Nebraska Sandhill lakes: bioenergetics modeling. Nebraska Game and Parks Commision, Federal Aid in Sport Fish Restoration Project F-118-R-4, Study I, Job 2.
Paukert, C.P., Willis, D.W. \& Klammer, J.A. 2002b. Effects of predation and environment on quality of yellow perch and bluegill populations in Nebraska sandhill lakes. North American Journal of Fisheries Management 22: 86-95.

Paukert, C.P., Stancill, W., DeBates, T.J. \& Willis, D.W. 2003. Predatory effects of northern pike and largemouth bass: bioenergetic modeling and ten years of fish community sampling. Journal of Freshwater Ecology 18: 13-24.

Pease, A.A. \& Paukert, C.P. 2014. Potential impacts of climate change on growth and prey consumption of streamdwelling smallmouth bass in the central United States. Ecology of Freshwater Fish 23: 336-346.

Perry, A.L., Low, P.J., Ellis, J.R. \& Reynolds, J.D. 2005. Climate change and distribution shifts in marine fishes. Science 308: 1912-1915.

Petersen, J.H. \& Kitchell, J.F. 2001. Climate regimes and water temperature changes in the Columbia River: bioenergetic implications for predators of juvenile salmon. Canadian Journal of Fisheries and Aquatic Sciences 58: 1831-1841.

Pierce, R.B. 2012. Northern pike: ecology, conservation and management history. Minneapolis, MN: University of Minnesota Press.

Pine, W.E. III \& Allen, M.S. 2001. Differential growth and survival of weekly age-0 black crappie cohorts in a Florida lake. Transactions of the American Fisheries Society 130: 80-91.

Pörtner, H.-O. \& Peck, M. 2010. Climate change effects on fishes and fisheries: towards a cause-and-effect understanding. Journal of Fish Biology 77: 1745-1779.

Post, J.R. \& Prankevicius, A.B. 1987. Size-selective mortality in young-of-the-year yellow perch (Perca flavescens): evidence from otolith microstructure. Canadian Journal of Fisheries and Aquatic Sciences 44: 1840-1847.

Rice, J.A., Breck, J.E., Bartell, S.M. \& Kitchell, J.F. 1983. Evaluating the constraints of temperature, activity and consumption on growth of largemouth bass. Environmental Biology of Fishes 9: 263-275.

Roeckner, E., Bäuml, G., Bonaventura, L., Brokopf, R., Esch, M., Giorgetta, M., Hagemann, S., Kirchner, I., Kornblueh, L., Manzini, E., Rhodin, A., Schlese, U., Schulzweida, U. \& Tompkins, A. 2003. The atmospheric general circulation model ECHAM5. Part I: model description. Report 349. Hamburg, Germany: Max Planck Institute for Meteorology.

Roff, D.A. 1984. The evolution of life history parameters in teleosts. Canadian Journal of Fisheries and Aquatic Sciences 41: 989-1000.

Seaburg, K.G. \& Moyle, J.B. 1964. Feeding habits, digestive rates, and growth of some Minnesota warmwater fishes. Transactions of the American Fisheries Society 93: 269285.

Shuter, B.J. \& Meisner, J.D. 1992. Tools for assessing the impact of climate change on freshwater fish populations. GeoJournal 28: 7-20.

Shuter, B. \& Post, J. 1990. Climate, population viability, and the zoogeography of temperate fishes. Transactions of the American Fisheries Society 119: 314-336.

Sogard, S.M. 1997. Size-selective mortality in the juvenile stage of teleost fishes: a review. Bulletin of Marine Science 60: 1129-1157.

Straile, D., Eckmann, R., Jungling, T., Thomas, G. \& Loffler, H. 2007. Influence of climate variability on whitefish (Core- 
gonus lavaretus) year-class strength in a deep, warm monomictic lake. Oecologia 151: 521-529.

Tonn, W.M. 1990. Climate change and fish communities: a conceptual framework. Transactions of the American Fisheries Society 119: 337-352.

Walther, G.-R., Post, E., Convey, P., Menzel, A., Parmesan, C., Beebee, T.J., Fromentin, J.-M., Hoegh-Guldberg, O. \& Bairlein, F. 2002. Ecological responses to recent climate change. Nature 416: 389-395.
Winder, M. \& Schindler, D.E. 2004. Climate change uncouples trophic interactions in an aquatic ecosystem. Ecology 85: 2100-2106.

Wuellner, M.R., Chipps, S.R., Willis, D.W. \& Adams, W.E. Jr 2010. Interactions between walleyes and smallmouth bass in a Missouri River reservoir with consideration of the influence of temperature and prey. North American Journal of Fisheries Management 30: 445-463. 